\title{
The Urgency of Using Police Diversion in Minor Crimes at the Investigation Stage in the Perspective of Restoration Justice
}

\author{
Edy Heriwiyanto ${ }^{1}$; Joice Soraya ${ }^{2}$; Deni Setya Bagus Yuherawan ${ }^{3}$ \\ ${ }^{1}$ Faculty of Law, University Brawijaya Malang, Indonesia \\ ${ }^{2}$ Faculty of Law, University PGRI Kanjuruhan Malang, Indonesia \\ ${ }^{3}$ Faculty of Law, University of Trunojoyo, Madura, Indonesia \\ http://dx.doi.org/10.18415/ijmmu.v8i4.2590
}

\begin{abstract}
Implementation of deviations at this stage of the research would be broad outlines, covering verbal warning, informal deviation, and formal deviation. The deviation tries to get the offending child to avoid the stigma of the formal judicial process. Consultation with the victim's family; the perpetrator; Superiors of prison officers; Social worker; The public and other parties determine or influence the children's actions as perpetrators. In this way, you will offer better justice to the victims and perpetrators of crime in the best interests of our future. The results showed that the discretion assigned to investigators can stop or perform versioning. This mechanism is limited to offenses punishable by less than 7 (seven) years of age, in this case not to the maximum protection of children who break the law. Based on the results of the investigation, the deviation, such as change in the manipulator, compared to the number of people reported or brought to the police, still minimal. At the practical level, there are still many obstacles in the implementation of the investigation redirection, from the legal aspect to the estimated time in which it was not possible to act maximally. In Cultural aspects of society, it is still difficult to change the mentality of families and communities. Necessary aspects of reforming the structure of the support infrastructure for the successful implementation of the diversion are required. This requires thorough training and socialization so that it can be effectively implemented in the investigation phase.
\end{abstract}

Keywords: Diversion; Investigation; Legal Protection; Minor Criminal Case

\section{Introduction}

Every year the legal subjects in conflict with the law experienced a significant increase. The background of legal subjects committing delinquency is certainly not the same as the background of adults in committing crimes. The delinquency of legal subjects is inseparable from the driving factors so that a legal subject can commit delinquency, then at the end informal criminal justice the action that is carried out places the legal subject in the status of a prisoner, of course, has considerable consequences in terms of the development of legal subjects. 
In law enforcement practice, the Police (investigator) has the authority to determine the position of the criminal offender not to continue or dismiss the case of the legal subject who is the perpetrator of the criminal act or conduct diversion against the legal subject who is the perpetrator of the criminal act. Based on Article 7 paragraph (1) letter $\mathrm{j}$ of Law of the Republic of Indonesia Number 8 of 1981 concerning Criminal Procedure Law, and Article 16 Paragraph (1) letter 1 of Law No.2 of 2002 concerning the Police of the Republic of Indonesia which is a reference in conducting diversions or discretion. This implies that only the implementation of diversion by law enforcement based on statutory regulations is justified by investigators. The implementation of diversion in law enforcement that deviates from the stipulated regulations will not only create negative perceptions of investigators.

The implementation of deviations in the investigative phase can be done through deliberations that involve legal entities and their parents/guardians, victims and/or parents' guardians, community counselors, and professional social workers based on a judicial approach that is less successful.

Diversion is used as a model that has the potential to have an impact on changes in the criminal justice process, especially in the investigation stage, which still faces its problems. The level of diversion practice with a restorative justice approach that has been carried out still raises questions, what is the reason for termination of an investigation by the police as an investigator. However, if cases of legal subjects in conflict with the law will be continued at the prosecution stage, why is the diversion mechanism with the restorative justice approach being attempted by investigators which only takes a long time, is very rigid and costs quite a lot of money.

The implementation of diversion against the legal subjects of the perpetrators of a criminal act will provide a new understanding to investigators without having to take away their liberty. It is hoped that it will be able to become an alternative to the settlement of cases of legal subjects who have committed criminal acts for the first time by suppressing the recovery of the victims.

This paper contains the urgency of using police diversion in minor crimes at the investigation stage in the perspective of restorative justice.

The word detour is derived from the English detour, which means avoidance or detour (Nandang Sambas, 2010). The diversion is commonly known as a form of court settlement for legal persons that began in 1985 in the United Nations' National Standard Minimum Rules for the Administration of Juvenile Justice (Beijing Rules). In this case, there is a different treatment for the laws concerned conflict with the law as compared to treating adults, so there is a formal settlement transfer mechanism that can be carried out by law enforcement officers while one of the guidelines for researchers to diversify while The investigation phase relates to the provisions of Article 18 of Law No. 2 of 2002 on the Indonesian National Police.

The notion of diversion is also included in Article 11.1 of the United Nations (Beijing) Standard Minimum Rules for the Administration of Juvenile Justice, which states that diversion is the granting of powers to law enforcement officers to take action to resolve or resolve problems. In this case, the investigator is empowered to take action, with community support or other forms of other measures, to prevent violations of legal subjects, including by not following the formal route, interrupting or aborting the criminal process, or returning it to the community forms social activities. Conceptually, it is not based on minor offenses, but rather on the importance of a diversionary mechanism for young legal subjects.

The implementation of the diversion program corresponds to that of the restorative justice program in the investigative phase, namely: Firstly, the implementation of social control (orientation towards social control). In this case, the law enforcement officer assigns the perpetrator the responsibility for monitoring or observing the public, taking into account the consent or warning given. The community 
is not expected to get a second chance for the perpetrator. Second, the community social services for the offender, in this case, the aim of punishment is the function of monitoring, removing, repairing, and providing services to the offender and his family so that the community can intervene in the offender's family to provide repairs or services; Third, distraction as an attempt to invite the public to comply with the law and enforce state law, enforcement continues to view the sense of justice as a top priority and provide offenders with the opportunity to pursue non-criminal avenues such as compensation and social work or supervision.

According to M. Yahya Harahap, the meaning of investigation is a follow-up action of an investigation in the presence of a criminal incident. Strict requirements and restrictions on the use of force after the collection of sufficient preliminary evidence to make clear an incident that can reasonably be suspected of being a criminal act (M. Yahya Harahap, 2006). Based on sufficient preliminary evidence it is not necessary to deprive the person of liberty in the best interest of the legal subject. Even so, legal subjects in conflict with the law can act independently but have not been able to protect themselves from the negative effects of further judicial processes in the administration of justice as legal subjects.

Article 29 of Law No. 11 of 2012, diversion can be carried out by investigators, in this case, the police conduct discretionary policies for legal subject investigators in determining a legal subject case of a criminal act, not being continued by the examination with legal considerations following legislation and in the best interest of legal subjects. Therefore, the investigator is authorized to exercise discretion by issuing a letter of determination to stop the investigation. However, in this thesis research, there is no Government Regulation on the implementation of diversion against legal subjects in conflict with the law.

Article 109 paragraph 2 of the Criminal Procedure Code states the reasons for granting authority to terminate investigations. 11 Referring to Article 29 paragraph (3) of Law No. 11 of 2012 concerning the Criminal Justice System. Legal subjects cease investigation of the legal subject of the criminal offender can be carried out if the determination of the result of a diversion agreement the social adviser has submitted it to the district court for a decision to be made, in this case, the fact that an investigator issues an SP3 before there is a determination of the diversion result from the District Court, of course, there will be potential for abuse of authority.

Legal protection for legal subjects in conflict with the law, in principle as stipulated in the convention on the rights of minor crimes which was later adopted in Law Number 23 of 2002 concerning the Child Protection, are some of the most important principles in protecting child as legal subjects, which are the basis for in various countries, especially Indonesia, are as follows: First, the principle of nondiscrimination so that the state is obliged to protect and respect the rights of minor crimes; Second, the principle of the best interests of child as legal subjects so that the protection of legal subjects is well organized; The third principle, the right to life, survival, and development, and the fourth principle, respect for the opinion of child as legal subjects.

\section{Research Method}

This research is a type of normative juridical research. The author's basis for choosing this type of research is because this study examines the juridical implications of using penal mediation as a nonlitigation settlement effort in the investigation stage using the local wisdom approach as a form of restorative justice approach.

Descriptive research is intended to make careful measurements of certain observed social phenomena. It is said to be descriptive because through this research it is expected to get a comprehensive and systematic picture of the juridical implications of using penal mediation as a non-litigation settlement effort in the investigation stage using the local wisdom approach as a form of restorative justice approach. 
This research is also normative legal research conducted through secondary data analysis and descriptive analysis which is more aimed at research on the juridical implications of using penal mediation as a non-litigation solution in the investigation stage using the local wisdom approach as a form of restorative justice approach. The focus of this research is more emphasized on library research.

\section{Research Result and Discussion}

Based on data on the application of diversion in the police, it has been practiced for a long time regarding the concept of diversion, even before the enactment in Article 1 point 7 of the Law on the Juvenile Criminal Justice System in 2012. In practice carried out at the investigative stage, it is in line with what is mandated by the Law on the Criminal Justice System for legal subjects regarding the restorative justice approach through diversion.

Broadly speaking, there are three forms of diversion, namely diversion in the form of warnings; Informal diversion and formal diversion must have a positive impact on victims, families, and legal subjects. Looking at the reality that occurs in resolving criminal cases committed by legal subjects, investigators as the party conducting the initial examination of legal subjects can be said to have made efforts that lead to the application of diversion (Marlina, 2008).

In this regard, it can be seen that the implementation of diversion in the Police will not carry out such peace efforts if previously there was no request from the disputing parties but this does not apply to general offenses. The parties in a lawsuit (or in other words not originating from the initiative of the police) are only committed to certain cases (complaints), but this does not apply to general offenses. After the peace was made, it was reported first to the leadership. If the leadership approves it, then the case is closed, but if the leadership does not approve it, then the case continues, or the files are transferred to the prosecutor's office.

Second, when the police in handling cases of legal subjects in conflict with the law, then efforts were made to diversify them. Therefore, when the case of the legal subject (with certain considerations) is about to undertake a diversion attempt, the police invite the parties concerned to carry out the subject of the diversion to attempt punishment. If the diversion attempt is successful, then the police will ask for a verdict to court (directly) without through the prosecutor's office. This stipulation is to validate the diversion efforts that have been carried out so that the case can stop or not continue to the next stage. However, when the effort is unsuccessful (fails), the police, as usual, namely the case continue, or the prosecutor's file is transferred.

The level of seriousness of the crime is always the first consideration for diversion and the law has divided crimes according to the level of seriousness. Although when dealing with children in conflict with the law, this level also sets a general standard on the seriousness of the act, the child has the right to be treated differently from adult criminals, and therefore the form and level of intervention must remain different. As a general rule of thumb, crime can be divided into 3 categories: light, moderate, heavy.

In general, children who commit minor offenses should diversify as much as possible. In the case of moderate criminal offenses/offenses, there are considerations for distraction. In serious crimes, distraction is not an option. Some crimes are classified as misdemeanors, such as B. Minor theft, minor attack without injury, or minor property damage. Delinquency / moderate offense is a type of offense that combines all the conditions. All conditions are taken into account in determining the eligibility of Distraction For serious crimes such as sexual assault and physical assault that causes serious injury, distraction is not an option. This diversion procedure can only be used for offenses with a sentence of fewer than 7 years and does not constitute a repetition of an offense (Article 7 (2) of the SPPA Act). 
Every situation involving a child as a perpetrator of a legal violation is different and unique. So the following factors need to be taken into consideration:

a. Type and conditions of action; The first consideration about the deviation is the severity of the act: if it is easy, moderate, or severe, the background of the act may be a reflection of previous violations that have been committed, if the child has previously committed minor violations of the law, deviation and Discretion If the child breaks the law frequently, it is difficult to diversify. However, it is necessary to take careful action and think carefully and in the best interests of the child, and it is necessary to refer to a Services's competent professional;

b. Degree of involvement of children in cases. Meanwhile, other parties are involved in an offense have planned it and take an active part, a child is usually only involved at the last minute and only acts as a lookout/watchman.

c. The degree to which a child is involved will play a major role in considering diversion and discretion for him;

d. attitudes of children towards these actions

e. The reaction of the parents and/or the child's family to the act. Support from parents and family is essential for successful diversion. If the family covers up the child's actions, an effective diversion plan will be difficult to implement.

f. Suggestions are made to make improvements or apologize to the victim. An apology to the victim is a clear indication to the victim that the child wants to be held accountable for their actions. If the child is unwilling to apologize for their actions, then the deviation. It is difficult; The effect of the act on the victim.

g. If the crime has very serious implications for the victim, even if the child didn't mean it, distraction may not be an option;

h. The victim's vision of the treatment method offered for the deviation to be properly planned, input and/or consent must be given with the victim;

i. The impact of previous sanctions or sentences on children: If the child has previously been exposed to the law and the child has not responded positively to the previous sanction, then a derogation cannot be considered unless the previous offense has been or is minor for a long time; If it is in the public interest, the legal process must take place.

It is explained in the general explanation of Law No.3 of 1997, that in dealing with and overcoming various actions and behaviors of naughty children, it is necessary to consider the position of the child with all its distinctive characteristics and characteristics. Even though the child has been able to determine his action steps based on his thoughts, feelings, and wills, the surrounding circumstances can influence his behavior. Because of the child's behavior.

In police practices related to the handling of criminal cases committed by minors, not all are delegated by the prosecutor, but some are resolved amicably by the interested parties. And to solve the crimes committed by children to differentiate them to protect and better care for children so that they can face their long futures. Also, this distinction should offer the children opportunities so that they can acquire their identity through coaching to become independent, responsible, and useful people for themselves, their families, communities, nation, and state.

In line with the subject matter raised, the discussion or analysis emphasizes the implementation of law enforcement agencies, in this case, the Police as one of the law enforcement agencies or organizations/bureaucracy in the field of investigation.

The activities carried out are related to the application of diversion and discretion against children who face the law at the level of investigation using the theory put forward by Robert B. Seidman, namely the theory of the operation of the law which says that "How will a law enforcement agency be working in 
response to legal regulations, is a function of the regulations addressed to it, the sanctions, the whole complex of social, political, and other forces that work on it, and the feedback that comes from the stakeholders (role occupants).

Based on the opinion expressed by Robert B. Seidman above regarding the law enforcement bureaucracy and its environment, it can be explained that the reality of the operation of the Police organization is to coordinate the use of resources to achieve organizational goals through people, techniques, and Techniques and information carried out within the framework of an organizational structure, in carrying out the intended functions/duties and authority, namely the application of diversion and discretion in restorative justice for children in conflict with the law at the level of investigation is carried out by following and fulfilling various restrictions determined by formal standards in the form of legal regulations relating to the problem of children who are dealing with the law.

Concerning the above functions/duties and powers, namely the use of distraction and discretion in restorative justice for children exposed to the law at the investigative level, the implementation of Polri's duties under Article 2 of the law. Issue 2 of 2002 on the Indonesian National Police, namely the role of the police is one of the tasks of the state government in the field of security and law enforcement, law enforcement, protection, enforcement, protection, and community service.

The main task of maintaining security and public order arises from the general duty of the police to ensure public safety, while the core of the main task of enforcing the law lies in the legal and regulatory provisions that contain the main functions of the national police force. About criminal justice, for example, the Criminal Code, the Criminal Code, and various other specified laws. Also, the main role of the police force is to provide protection, protection, and service to the community. This arises from the position and function of the police as part of the function of the state government, which is essentially a public service (public service) that is included in the general obligations of the police.

Between the investigation and the investigation, two phases of action become one to be carried out by the investigator and the investigator (Polri officers or "Officials of the State Police of the Republic of Indonesia" according to the provision of the Criminal Procedure Code) including activities to search and search for an event that is suspected of being a criminal offense; determine whether an investigation can be conducted; Seek and collect evidence; Clarification of the offense that has occurred; and determine the suspect of the crime.

The investigation, which is the first contact between children in conflict with the law (offense) and the police, is well suited to the importance of observing the points 5,6, 7, 8, and 9 established management principles at the investigation level highlighted by Article 1 of Law No.3 of the 1997 year.

Based on the above articles, the investigation of children, especially children with legal problems, is essentially in line with the opinion expressed by Yahya Harahap that the "investigation" is the first phase of the action or the beginning of the action. It should be noted, however, that an investigation is not an action that deviates from the "Investigation" function. The investigation is an essential part of the investigation function. Following the words used in the Guidelines for the Implementation of the Criminal Code, the investigation "is one of the methods or sub-functions of investigation that precede other acts, namely the act of arrest, detention, registration, seizure, examination of letters, Subpoenas, investigations, and referral of files to the Attorney General".

Based on these facts, it can be seen that in the handling of cases of legal subjects in conflict with the law, there is a shift in the viewpoint of investigators to resolve through a diversion mechanism. Qualitatively, the number of legal subjects in conflict with the law that can be resolved through a diversion mechanism is very minimal compared to cases that are reported or filed. It can be seen that the 
settlement through the diversion mechanism on cases of minor crimes, namely ordinary theft, the obscenity of underage legal subjects, light maltreatment. The same is true of the diversion mechanism that was successfully carried out, namely theft, beatings in public, minor traffic accidents, and fights between students.

As for the obstacles faced by investigators (the Police) in implementing diversion, namely, sometimes the victim or the victim's family does not agree to the settlement using the diversion method through the restorative justice approach or in a peaceful manner and in the implementation of diversion it requires the consent of the victim to seek diversion. this becomes an obstacle for investigators so that its implementation is still ineffective.

That being said, there is one thing that is still denounced by the police today, which is the lack of government regulation on guidelines for implementing the diversion process, procedures, and coordination of guidelines for implementing diversion in the prison system of justice. For legal entities, The diversion process is done through counseling involving the legal entities and their parents/guardians, victims and/or their parents/guardians, community counselor,s and professional social workers based on a restorative justice approach.

Negotiating process in a family setting, honestly and without coercion, indicating that victims and their immediate loved ones must be active in the distraction process for the recovery process to be achieved by restorative justice. This leads to the need for an exchange of information between the victim and the perpetrator of the crime directly so that a beneficial agreement between both is the result of the crime committed; However, this is very difficult when the victims tend to be kidnapped or protected by their relatives so that they are not present during the diversion process. Of course, it will be difficult for law enforcement to make the best decisions for these legal subjects (Taufik Rahcman, 2010).

Bapas have an important role in the process of investigating the subject of punishment for the duties and functions of community research, guidance, supervision, assistance, and the diversion process. Not being able to act professionally, so that at the operational level it is necessary to increase resources, and the number of Bapas in each district, as well as facilities and infrastructure to support their performance in the field (in making community research), require special attention and the extent to which diversion is successful on these legal subjects.

The diversion of legal entities in contravention of the law may lead to agreements on the implementation of the diversion, namely: peace with or without compensation for losses; Return to parent / legal guardian; Participation in education or training in educational institutions, social administration institutions or social institutions; Therefore, at the implementation level of educational institutions, social services, and non-profit programs, they must be able to act as a forum or agent to transform the perpetrator's behavior into a smart and skilled person. On a practical level, it is still debatable, there are still few programs that speak for the legal entity and structural improvements need to be made to support the interests of the legal entity.

As a result of the absence of government regulations related to the Guidelines for the Implementation of Diversion in the Criminal Justice System. Legal subjects in connection with that the results of the diversion agreement must be subject to the punishment must go through a formal process involving the court, of course, it will bring legal consequences in the future.

In this regard, the stipulation referred to is new and different from the previous rulings because it relates to the status of the 'aquo' case. Substantially stated that the parties carry out the subject of the outcome penalty diversion, to the official in charge of the case to immediately issue an Order to Stop Investigation (SP3). The decision to terminate the examination of the 'aquo' case and order the Bapas to 
send a copy of the ruling to the parties concerned (investigators, victims/perpetrators of criminal acts, public prosecutors) are still experiencing various obstacles at the investigation stage (M. Yahya Harahap, 2006).

In connection with the authority possessed by the police, the police apparatus can exercise or use discretionary powers rather than having to continue the legal process. In this case, it is known as police discretion, which is the authority of the police to stop case investigations by acquitting a suspect or carrying out a diversion (diversion), and the goal is to avoid children from further legal proceedings.

In Indonesia, the police apparatus has discretionary powers, as stipulated in Article 18 of Law no. 2 of 2002, which stipulates that in the public interest, Polri officials in carrying out their duties and authorities can act according to their judgment. One of the discretionary powers is through the act of diversion and of course, the act of diversion that is carried out must not violate the applicable legal rules.

Based on this provision, the police are given special authority (discretion) to carry out diversions that keep away from the formal justice process, detention or imprisonment. This diversion program can be carried out in various ways, including by placing under the supervision of certain social agencies to help the child solve the problems he is facing.

Also, based on Telegram Head of Criminal Investigation Police No. Pol .: TR / 1124 / XI / 2006, diversion can be carried out in the form of returning to the child's parents, either without or accompanied by informal warnings or carrying out mediation, such as becoming an intermediary to communicate or facilitate the fulfillment of victims' needs and protection of minor crimes within the framework the goal of solving problems that arise as a result of his actions.

The handling of minor crimes through diversion acts as an effort to realize justice, although according to Mochtar Kusumaatmadja and B. Arief Sidharta it is said that justice is difficult to define, but can be felt and is an element that cannot be separated from the law as a set of principles and rules that guarantee. there are order and order in society Actually, the measure of the value of justice can be seen from two aspects. In addition to the ideal aspect, the value of justice has an empirical aspect, meaning that the measure of the value of justice in the legal context (ideal aspect) must be actualized concretely according to its benefits (empirical aspect).

With the existence of a measure of the benefits of the value of justice, justice can be viewed according to an empirical context. Based on this opinion, it can be said that the measure to say that an action has met the value of justice cannot be measured only by referring to the provisions of law, but must also be measured based on the value of its enforceability in society. The essence of justice is an assessment of treatment or action that studies it with a norm according to a subjective view (subjective for the interests of the group, class, etc.) which exceeds other norms. In terms of the concept of justice, there are two parties involved, namely those who treat and those who receive treatment. In general, justice is an assessment that is only seen from the party receiving the treatment, even though justice should be seen from both sides parties (Setya Wahyudi, 2011).

In the Indonesian criminal law system, a concept of justice has developed which does not only see justice from one side only, but also judges it from the interests of various parties, both the interests of the victim, the community, and the interests of the perpetrator. Justice that is meant here is not justice, which means punishing according to the actions of the perpetrator, but a justice known as restoration justice.

Tony Marshall as quoted by Taufik Hidayat states that restorative justice is a process that involves all parties to crime, especially to solve together how to deal with the consequences of a crime 
and its implications in the future. The UN Working Group, as quoted by Rena Yulia Nuryani, states that restorative justice is a process that involves all parties related to certain criminal acts together to solve problems and think about how to deal with consequences in the future.

In solving criminal cases that use a restorative justice approach, emphasizing the direct involvement of the parties and demanding collaborative efforts with the community and the government to create a harmonious environment, so that victims and perpetrators can reconcile their conflicts and resolve their losses and in time which simultaneously creates a sense of security in society.

The concept of restorative justice allows victims, perpetrators, and the community to be directly involved in responding to crimes. They become central in the criminal justice process, meanwhile, the state and professionals become facilitators of a system that aims at accountability for perpetrators of crime, compensation for victims, and full participation of victims, perpetrators, and society. The recovery process involves all parties which is the basis for achieving restorative results from restoration and peace.

The implementation of the concept of restorative justice contains 3 (three) main principles, namely: first, that justice requires people who can work together to restore people who have suffered, second, that those who are directly involved and who are affected by crimes must have the opportunity. participate fully to respond if needed, and third, that the laws and regulations are to protect the public interest, the community that builds and maintains peace.

Adrianus Meliala's opinion as quoted by Poernomo Gontha Ridho describes the concept of restorative justice as an effort to resolve conflicts and at the same time cure between perpetrators and victims. The trick is to bring together or introduce the perpetrator in one forum with the victim or his family to foster empathy on both sides. In Indonesia, a murderer who is found guilty is sent to a correctional facility. The problem ended there, while the feelings of the victim's own family and the feelings of the perpetrator when they saw the victim's suffering both did not know. Also, the perpetrator who has been sent to a correctional facility will do the same when he leaves prison. With the concept of restorative justice, it is hoped that the perpetrator will understand and realize that the consequences of his actions have made other people suffer and the victim no longer holds a grudge.

In particular, there is no statutory provision in Indonesia that establishes a standard for diversion measures for handling minor crimes but refers to the provisions contained in Article 18 of Law no. 2 of 2002, the handling of minor crimes should not be carried out by following the formal criminal justice system. In other words, according to their authority, in the handling of minor crimes, the police can more freely take action in the form of diversion outside the formal criminal justice system.

In fact, in Indonesia, there are many customary laws with the concept of restorative justice that can be passed, but their existence is not recognized or codified in national law. The customary law treaty can resolve conflicts that arise in the community and therefore bring satisfaction. The idea of restorative justice was developed as a criticism of the application of the criminal justice system with incarceration, which is seen as ineffective in resolving social conflicts because the parties involved in the conflict were not involved in conflict resolution. Victims are still victims, imprisoned perpetrators also create new problems for their families, etc.

The implementation of the distraction can be a form of restorative justice if the implementation of that distraction can encourage children to take responsibility for their actions and children the opportunity offers to compensate for the injustice committed by doing good to the victim, offer the victim opportunities to bond to participate in the process, offer the child the opportunity to maintain family relationships, and offer opportunities for reconciliation and Healing in communities harmed by criminal acts. 
The implementation of this method is done to achieve the best interests of the children on the principle of the child's best interests. In other words, the diversion is based on protecting the child and fulfilling the rights of the child (child protection and authorization based on full respect for the rights of the child), but this process of distraction can work well when all parties play their respective roles Parents, enforcers, the judiciary and society. Implementation of the distraction is the responsibility of all parties so that when the victim and perpetrator get their best, the focus is on restoring rapport to their original state and non-retaliatory action can be properly carried out without either party To inflict harm and, on the other hand, to harm the other party (Made Ayu Citra Maya Sari, 2012).

The handling of minor crimes should not be done with a retributive approach, but through a more educational approach that fulfills a sense of justice, namely through the restorative justice approach. The reason is that minor crimes themselves are not infrequently the victim of criminal acts, especially if they are children who still have a long future. As law enforcers, police officers are required to be able to handle minor crimes with a restorative justice approach, so that minor crimes do not always have to be punished based on the applicable provisions in the formal criminal justice system.

The handling of minor crimes without having to go through the criminal justice system is the discretionary authority of the police as regulated in Article 18 of Law no. 2 of 2002. Therefore, in the effort to handle minor crimes, police officers are allowed to take action of diversion (diversion) for the settlement of cases outside the existing formal criminal justice system. The discretionary power to carry out this diversion is also based on UN Resolution No. 40/33 of 1985 (The Beijing Rules) and in line with the Telegram of the Head of Criminal and Criminal Investigation Police No. Pol .: TR / 1124 / XI / 2006.

Based on these provisions, the law will better fulfill a sense of justice, if in handling minor crimes it can provide benefits to many parties, not only for the perpetrator but also for the wider community, because the purpose of the law is also to provide benefits in producing the greatest pleasure or happiness for the number the most people. The police apparatus, which in their functions and duties as law enforcement officials as well as protectors and protectors of the community, are required to be able to carry out a restorative justice approach in the handling of minor crimes, to improve the existing judicial system. This means that it is more like restoring or improving, which can change the approach to the concept of justice that is appropriate in investigating juvenile criminal cases.

Where the supervision of the implementation of diversion is under the direct supervisor who is responsible for monitoring. If the results of the diversion agreement are not carried out properly, the perpetrator or his family does not complete their obligations. In this case, the Bapas directly conveyed to the investigator that they had to proceed to the formal investigation stage, meanwhile the investigator had issued a letter of dismissal of investigation. This will be very crucial if there is no report from Bapas to investigators whether the diversion process has succeeded in making the legal subject better.

The investigation is a compensation for investigators to terminate (Article 109 paragraph 2 of the Criminal Procedure Code), but if the termination of the investigation of the legal subject of the criminal offender because the result of the diversion has not yet regulated the mechanism for issuing a letter stipulating the termination of investigation concerning the Criminal Justice System for Legal Subjects and the Criminal Procedure Code. Where in this thesis research there is no government regulation, which regulates the termination of the diversion process investigation. Some investigators issued a letter of dismissal of investigation before the decision of diversion from the district court.

The implementation of diversion at the investigation stage provides space to ensure legal justice for legal subjects. Many of the benefits obtained from implementing a diversion program for legal subject actors can be stated as follows: 
1. Helps juveniles learn from their mistakes through early intervention (helping legal-legal subjects learn from their mistakes through intervention as soon as possible);

2. Repairs the harm caused to families, victims, and the community (repairing injuries caused by the incident, to families, victims, and communities);

3. Incorporates parents, guardians, and lessons from everyday life (collaboration with parents, caregivers and given daily life advice);

4. Equips and encourages juveniles to make responsible decisions (equipping and raising legal subjects to make decisions to be responsible);

5. Creates the mechanism to collect restitution for victims (trying to collect funds for restitution to victims);

6. Holds youth accountable for their actions \& provides learning opportunities regarding causes and effects (giving legal subjects responsible for their actions, and providing lessons about opportunities to observe the consequences and effects of the case);

7. Allows eligible offenders the opportunity to keep their record clear (giving options for perpetrators to have the opportunity to keep them clean of criminal disabilities);

8. Reduces burden on the court system and jails (reduces the burden on the judiciary and prison institutions);

9. Curbs juvenile crime (Made Ayu Citra Maya Sari, 2012).

From the benefits of diversion that have been mentioned above, the investigator should have been able to make more efforts for diversion. The diversion effort is a mandate of the Law on the Criminal Justice System for legal subjects, and the diversion effort has many benefits because it can reduce the number of cases of legal subjects that are continued at the prosecution stage. The investigators have more time because they do not have to carry out a formal trial which has been attempted to be diversified and there is no accumulation of cases.

A formal diversion process where the victim and the perpetrator meet face to face, which aims to achieve restorative justice, one of which is family group deliberation.15 Thus the restorative justice process in which victims and perpetrators or other individuals or members of the community are influential in taking an action against legal subjects who conflicted with the law.

\section{Conclusion}

Based on the analysis of the problems in this study, conclusions are obtained in the form of:

1. When implementing distraction and discretion, the focus is on: preventing child detention; Avoid calling children criminals. Improving actors' life skills; Hold the perpetrator responsible for his or her actions; To avoid repeating a crime; Promote the necessary interventions for victims and perpetrators without going through a formal process; Distraction will also prevent children from entering the judicial system processes; and it will also keep children away from the negative impact and impact on the psyche and development of children through their participation in the criminal justice system, as it turns out that when children are punished by the formal criminal justice system, children do not succeed in jailing discourage it and become better people to aid the process of growth and development. Prison often makes children more professional in committing crimes.

2.The application of diversion at the stage of the investigation as a settlement of minor crimes cases that committed a criminal act had already begun. A diversion is a form of the implementation of discretion given to investigators to avoid child as legal subjects from the formal justice process. However, at the practical level, there are still various obstacles from a juridical perspective, there are no government regulation guidelines for the implementation of diversion against child as legal subjects that conflict with the law, structurally it is necessary to improve the supporting facilities to successfully implement 
diversion of these child as legal subjects and no less important the cultural culture of the people still relies a lot upon justice formally.

3. Diversion is the best effort that can be done to protect the rights of minor crimes perpetrators of criminal offenses at the stage of the investigation, by pressing for recovery of victims and pushing child as legal subjects of the perpetrators of crimes to be accountable for the actions they have committed. The level of diversion practice at the investigation level is still minimal compared to the number of cases reported. Only limited to minor crimes such as ordinary theft, light maltreatment, and light maltreatment, brawls between students, and traffic accidents are classified as minor.

\section{References}

\section{Books and Journal}

M. Yahya Harahap, Pembahasan Permasalahan Dan Penerapan KUHAP: Penyidikan Dan Penuntutan, Sinar Grafika, Jakarta, 2006.

Made Ayu Citra Maya Sari, Diversi Dalam Sistem Peradilan Pidana Subyek hukum Di Indonesia, Artikel Hukum dan Sistem Peradilan Pidana, Pascasarjana Universitas Udayana, 2012.

Marlina, Penerapan Konsep Diversi Terhadap Subyek hukum Pelaku Tindak Pidana dalam Sistem Peradilan Pidana Subyek hukum, Jurnal Equality, Vol. 13. No.1 Februari 2008.

Nandang Sambas, Pembaruan Sistem Pemidanaan Subyek hukum di Indonesia, Graha Ilmu,Jogjakarta, 2010.

Setya Wahyudi, Implementasi Ide Diversi Dalam Pembaruan Sistem Peradilan Pidana Subyek hukum Di Indonesia, Genta Publishing, Yogyakarta, 2011.

Sunaryo, Perlindungan Hukum Atas Hak Asasi Manusia Bagi Subyek hukum Dalam Proses Peradilan Pidana, Fakultas Hukum Unsoed,2002, Purwokerto.

Taufik Rachman, Dasar Teori Kewenangan Penyidik Maupun Penuntut Umum Dalam Menghentikan Perkara Pidana, Jurnal Yuridika: Volume 25 No.3, September-Desember 2010.

\section{National Instrument}

Constitution of the Republic Indonesia of 1945.

Law of the Republic of Indonesia Number 8 of 1981 concerning Criminal Procedure Law

Indonesia Criminal.

Law of the Republic of Indonesia Number 39 of 1999 concerning the Human Right.

Law of the Republic of Indonesia Number 2 of 2002 concerning the Police of the Republic of Indonesia.

Law of the Republic of Indonesia Number 23 of 2002 concerning the Child Protection.

Law of the Republic of Indonesia Number 11 of 2012 concerning the Juvenile Criminal Justice System.

\section{Copyrights}

Copyright for this article is retained by the author(s), with first publication rights granted to the journal.

This is an open-access article distributed under the terms and conditions of the Creative Commons Attribution license (http://creativecommons.org/licenses/by/4.0/). 